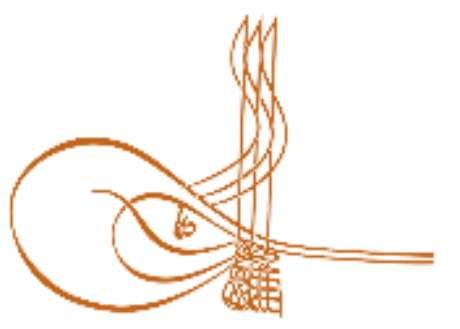

www.turkishstudies.net/turkishstudies
Turkish Studies

eISSN: $1308-2140$

Research Article / Araştırma Makalesi

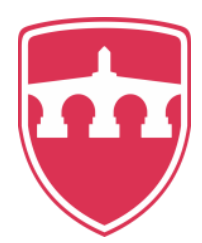

INTERNATIONAL

BALKAN

UNIVERSITY

Sponsored by IBU

\title{
36-72 Aylık Çocukların Mesleklere Yönelik Oluşturdukları Toplumsal Cinsiyet Algıları
}

Gender Percepilons of 36-72 Months Preschool Children Related to Professions

\author{
Erhan Alabay ${ }^{*}$ - Gülsüm Özdemir ${ }^{* *}$
}

\begin{abstract}
The aim of this study was to determine the gender perceptions of 36-72 months old children attending preschool education related to professions. This research was a quantitative research design and modeled according to descriptive scanning method. In this study, the study group consists of a total of 200 children, 36-72 months old, who are studying in private and public pre-primary education classes in the Anatolian side of Istanbul. The determined schools were determined by an easily accessible sampling method, and the children selected from the schools were determined by random sampling method. In the research, the structured "Who Makes This Profession Form" developed by the researchers, 18 picture cards with the tools used by the people doing the professions and picture cards with only women, only men and both women and men pictures were used. In this study, each child was studied individually and the collected data were analyzed in SPSS 21.0 statistical program. According to the findings of the study, children mostly were choose as the male profession which repairers (87.5\%), construction machinery users (83.0\%) and the captain (76.5\%). On the other hand, children mostly were choose as the female profession which Nurses (60.0\%), tailors $(53.0 \%)$ and teachers $(47.5 \%)$. A significally relationship was found between the variables of age and the level of selection of some occupational groups (doctor, fireman, teacher, nurse, cook, tailor, announcer, singer and cashier). In addition, the presence of male teachers in the institutions where children are enrolled revealed that children were more egalitarian towards the professions.
\end{abstract}

Structured Abstract: Introduction Many countries carry out a number of studies and projects to minimize or completely eliminate gender inequalities (Baker, Ali and French, 2018; Graham and Chattopadhyay, 2013). Most of these studies are aimed at children in early childhood. Because gender stereotypes are learned and formed in early childhood. Children learn gender stereotypes from many factors such as family, peer, educator, or social platform. Gender equality taught in childhood continues in adulthood. Therefore, studies on gender equality in early childhood are needed (Fang, 2010; Bian, Leslie and Cimpian, 2017).

\footnotetext{
* Dr. Öğr. Üyesi, Sağlık Bilimleri Üniversitesi Sağlık Bilimleri Fakültesi Çocuk Gelişimi Bölümü Asst. Prof. Dr., University Of Health Sciences/Faculty Of Health Sciences/Department Of Child Development ORCID 0000-0003-4025-2352

erhan.alabay@sbu.edu.tr

** ORCID 0000-0001-6840-2127

gulsumozdemir9@gmail.com

Cite as/ Atıf: Alabay, E., Özdemir, G. (2020). 36-72 aylık çocukların mesleklere yönelik oluşturdukları toplumsal cinsiyet algıları, Turkish Studies, 15(1), 13-29. https://dx.doi.org/10.29228/TurkishStudies.37370

Received/Geliş: 19 September/Eylül 2019

Accepted/Kabul: 25 February/Şubat 2020

Checked by plagiarism software

Copyright $(\mathcal{C}$ MDE, Turkey

Published/Yayın: 29 February/Şubat 2020

CC BY-NC 4.0
} 


\section{Purpose}

The aim of this study was to determine the gender perceptions of 36-72 months old children attending preschool education related to professions. For this basic purpose, the following research questions were sought:

1. Which gender do preschool children think of doctor, police, fireman, pilot, football player, mechanic, construction equipment user, astronaut, captain, teacher, nurse, cabin attendant, cook, cleaning staff, tailor, announcer, singer, cashier?

2. Is there a meaningful relationship between the gender of the occupations chosen by the child and the sex of the child, the age of the child, how many years he has been attending kindergarten, the education and age of the mother, the education and age of the father, the number of siblings and the presence of a male teacher in the institution the child is attending?

\section{Method}

This research was designed with a quantitative research model. One of the quantitative research models, descriptive scanning model was used. In this study, the study group consists of 200 children aged 3672 months who are attending private and state preschool classes in the Anatolian side of Istanbul. In the study, the data collection tools were used by the researchers, the child demographic information form, 18 different professional cards and the "Who Makes This Profession?" questionnaire form. In the child demographic information form prepared by the researchers, there are a total of 9 closed-ended questions including gender, age, attendance to kindergarten, maternal education and age, father's education and age, number of siblings, and presence of male teachers in the institution. In addition to this, the forms that allow the researcher to mark only the female / male only / male and female options selected by the child in accordance with the picture cards shown to the child are given on this form. The cards used in the research included the following occupations: doctor, police, fireman, pilot, footballer, mechanic, construction equipment user, astronaut, captain, teacher, nurse, cabin attendant, cook, cleaning staff, tailor, announcer, singer, cashier. The cards do not include people who do the profession. The cards contain only the tools used by the professions. The researchers conducted one-to-one interviews with children. Each of the interviews was conducted in the child's own school and in an empty classroom. Each of the children was asked questions with the same verbal expression. "Now I'm going to show you cards with pictures on it. These pictures have things that some professions do. They look at these pictures and tell me the name of this profession and then the people who do this job, whether it's a woman or a man or a woman or a man? I want you to show me the pictures " On average, the application was 7-10 minutes with each child.

\section{Results}

The occupations that children think only to be specific to women are Nurse (60\%), Tailor (53\%), Teacher (47.5\%), Cook (39.5\%) and Cleaning Staff (41.5\%). The occupations that children think of are specific to men are Repairman (87.5\%), Construction Equipment User (83.0\%), Captain (76.5\%), Footballer (73.5\%), Pilot (67.5\%), Fireman (66,5\%), Police (64,5\%), Announcer (49,0\%), Singer $(47,5 \%)$ and Cabin Officer $(36,5 \%)$. The occupations that the children think for both men and women are Cashier $(52.5 \%)$ and Doctor $(48.5 \%)$. Another finding from Table 2 is that only 5 of the 18 professions of children are selected exclusively for women and 10 of them are selected exclusively for men. It is seen that occupational perceptions for men are much higher than occupational perceptions for women. As the age of the children, the age of the parents and the education level of the parents increased, the gender stereotypes regarding the occupations of doctors, firemen, teachers, nurses, cooks, tailors, announcers, singers and cashiers were reduced and that gender equality was perceived that both women and men could do these professions. It was concluded that increased. It has been concluded that the gender stereotypes of the children with male teachers in the institution where they are educated have decreased and the gender egalitarian perception that both women and men can perform these professions has increased.

Keywords: Gender, preschool children, occupations.

Öz: Bu araştırmanın amacı, okul öncesi eğitim kurumuna devam eden 36-72 aylık çocukların mesleklere yönelik oluşturdukları toplumsal cinsiyet algılarını belirlemektir. Bu araştırma nicel araştırma deseninde 
çizilmiş olup, betimsel tarama yöntemine göre modellenmiştir. Bu araştırmada çalışma grubunu, İstanbul ili Anadolu yakasında Milli Eğitim Bakanlığına bağlı özel ve devlet okul öncesi eğitim sınıflarında öğrenim görmekte olan 36-72 aylık toplam 200 çocuk oluşturmaktadır. Belirlenen okullar kolay ulaşılabilir örneklem yöntemi ile belirlenmiş olup, okullardan seçilen çocuklar ise rastgele örnekleme yöntemine göre belirlenmiştir. Araştırmada, araştırmacıların geliştirdiği yapılandırılmış "Bu Mesleği Kim Yapar Formu”, meslekleri yapan kişilerin kullandıkları araçların bulunduğu 18 adet resim kartı ve üzerinde sadece kadın, sadece erkek ve hem kadın hem erkek resimlerinin bulunduğu resim kartları kullanılmıştır. Araştırmada her bir çocukla bireysel çalışılmış, toplanılan veriler SPSS 21.0 istatistik programında analiz edilmiştir. Çalışmanın bulguları doğrultusunda çocuklar tarafindan sadece erkekler tarafından yapıldığ 1 belirtilen mesleklerin başında tamirci $(\% 87,5)$, iş makinesi kullanıcısı $(\% 83,0)$ ve kaptan $(\% 76,5)$ gelmekte iken; kadınlar tarafından yapıldığ belirtilen mesleklerin başında ise hemşire $(\% 60,0)$, terzi $(\% 53,0)$ ve öğretmen $(\% 47,5)$ gelmektedir. Çocukların yaşı ile bazı meslek gruplarını (doktor, itfaiyeci, öğretmen, hemşire, aşçı, terzi, spiker, şarkıcı ve kasiyer) seçme düzeyleri arasında istatistiksel olarak anlamlı ilişkiye rastlanmıştır. Ayrıca çocukların eğitim gördükleri kurumlarda erkek öğretmen bulunma durumu çocukların mesleklere karşı daha eşitlikçi yaklaştığı sonucunu ortaya çıkartmıştır.

Anahtar Kelimeler: toplumsal cinsiyet, okul öncesi, çocuk, meslekler.

\section{Giriş}

Dünya Ekonomik Forumu (World Economic Forum - WEF), her y1l yapılan "Küresel Toplumsal Cinsiyet Uçurum Raporu" doğrultusunda toplam 149 ülkenin toplumsal cinsiyete dayalı eşitsizliğinin istatistiklerini yayımlamaktadır. 2018 yllında yayımlanan rapora göre, toplumsal cinsiyet eşitsizliğinin en az olduğu ülkelerin başında İzlanda, Norveç ve İsveç gelmekteyken, toplumsal cinsiyet eşitsizliğinin en çok olduğu ülkelerin başında ise Yemen, Pakistan ve Irak gelmektedir. Türkiye ise evrensel ortalamanın altında 130. sırada yer almaktadır. 2006 yılından 2018 yılına kadar yapılan tüm raporlar incelendiğinde, Türkiye'deki cinsiyet eşitsizliği rakamlarında düşme olduğu görülmektedir. Türkiye için işgücüne katılım oranlarında cinsiyet farkının yavaş yavaş kapandığ 1 ve mesleki ve teknik rollerde ilerleme kaydettiği 2018 raporunda belirtilmiştir. Fakat bu durumun yeterli olmadığ 1 görülmektedir. Dünya Bankasının (World Bank) (2019) yayımlamış olduğu “Toplumsal Cinsiyet Veri Kitabı"nda Türkiye'deki 2000 ve 2017 yılı eğitim, sağl1k, ekonomi ve yaşam üzerine erkek ve kadınların yararlanma oranları karşılaştırılmıştır. Benzer olarak 2000 yılındaki toplumsal cinsiyet eşitsizliği oranları 2017 de azaldığ gözlemlenmekte, fakat hala erkeklerin kadınlara oranla eğitim, sağlık, ekonomi ve yaşam alanlarından daha fazla yararlandığı gözlemlenmektedir. Özellikle istihdam alanında kadınların oranlarının erkeklerin oranından oldukça az olduğu raporda belirtilmiştir.

Ülkeler, kendi içerisinde bulunduğu bu toplumsal cinsiyet eşitsizliklerini en aza indirgemek veya tamamen ortadan kaldırmak amacıyla birçok çalışma ve proje gerçekleştirmektedir (Baker, Ali ve French, 2018; Graham ve Chattopadhyay, 2013). Bu çalışmaların birçoğu ise erken çocukluk dönemini kapsayan çalışmalardır. Örneğin toplumsal cinsiyet eşitliğinin üst seviyede olduğu İskandinav ülkelerinden birisi olan İsveç'te cinsiyetsiz anaokulları açılmıştır. Cinsiyetsiz anaokullarında müfredat, eğitim ortamı ve eğitim materyalleri tamamen geleneksel cinsiyet rollerine karşı koymaktadır. Çocuklar bu eğitim ortamlarında hiçbir materyali kız veya erkek materyali diye ayırt etmeden kullanmaktadır. Eğitim materyallerinde geleneksel cinsiyet yapılarını içerek kırmızı başlıklı kız veya kül kedisi gibi masal kitapları yerine, eşitlikçi yapıdaki hikaye kitapları kullanılmaktadır (Acar Erdol, 2019). Türkiye'de de "Eğitimde Toplumsal Cinsiyet Eşitliğinin Geliştirilmesi Projesi” sürdürülmektedir. Bu projenin temel amacı ise toplumsal cinsiyet eşitliği bilincini sağlamak, yaygınlaştırmak ve eğitim sistemin içerisine aktarmaktır. Bu proje doğrultusunda erken çocukluk eğitiminde uygulanan müfredatlarının içerisine toplumsal cinsiyet eşitliğini destekleyen etkinliklere yer verilmesi sağlanmaktadır. İlgili proje 10 farklı pilot şehirde uygulanmış ve her bir pilot ilden 4'er okul seçilmiştir. Bu belirlenen okullarda 24 ay süresince toplumsal cinsiyet 
eşitliği üzerine eğitimler uygulanmıştır (ETCEP, 2017). Yukarıda verilmiş örnek projeler gibi birçok proje erken çocukluk döneminde başlanlaması gerektiğini vurgulamaktadır. Çünkü toplumsal cinsiyet kalıpyargıları öğrenilen bir yapıdır. Toplumsal cinsiyet eşitliği üzerine yapılan çalışmaların temel hedefleri incelendiğinde, öncelikle çocuğun toplumsal cinsiyet eşitsizliğine neden olan faktörleri değiştirmeye veya engellemeye çalışmak olduğu görülmektedir. Bu nedenle öncelikle bu kalıpyargıları oluşturmasına etken olan faktörlerin belirlenmesi gerekmektedir. Aile, akran, eğitimci veya sosyal platform gibi birçok faktör çocuğun toplumsal cinsiyet kalıp yargılarını şekillendirmektedir (Connel, 1998; Terzioğlu ve Taşkın, 2008). Bu nedenle çocukluk çağında öğretilecek olan her alanda cinsiyet eşitliği, yetişkinlikte de devam edeceği için (Çelik, 2008) özellikle erken çocukluk döneminde toplumsal cinsiyet eşitliğine dayanan çalışmalara ihtiyaç duyulmaktadır (Fang, 2010; Bian, Leslie ve Cimpian, 2017).

Günümüzde özellikle ataerkil yapı içerisinde yetiştirilmiş olan çocuklarda birçok kavram veya durum cinsiyet farklılaşmasına yol açmaktadır. Örneğin, bu şekilde büyütülmüş çocuklarda pembe renginin kız çocukları, mavi renginin ise erkek çocukları tarafindan tercih edilen bir renk olduğu; bebeklerin kız çocukları, kamyon veya tamir oyuncaklarının erkek çocukları tarafından tercih edilen oyuncak türleri olduğu düşünceleri hakimdir. Çocukların bir diğer cinsiyetleştirdiği konu ise mesleklerdir. Karabekmez ve arkadaşları (2018) okul öncesi dönem çocuklarının mesleklere dair oluşturdukları cinsiyet algılarını belirlemek amacıyla yaptıkları çalışma sonucunda, erkeklere yönelik meslek algılarında en yüksek oranda şoförlük ve tesisatçılık mesleği yer alırken, kadınlara yönelik meslek algılarında ise terzilik başta gelmektedir. Gündüz Çetin ve Tarhan (2017)'in ilkokul öğrencilerinin meslek seçimine dair tutumlarında toplumsal cinsiyetin etkisi olup olmadığını belirlemek amacıyla yaptıkları araştırmasında, erkek öğrencilerin kız öğrencilere oranla meslek seçimlerinde bazı mesleklerin kadınlar tarafından yapılamayacağ 1 konusunda daha katı düşünceye sahip olduğu sonucuna ulaşmışlardır. Nicolao (2014) öğrencilerin meslek seçerken toplumsal cinsiyet kalıpyargılarının etkisinin olup olmadığını belirlemeye çalıştığı araştırmasında, çocukların meslek seçerken içinde yaşamış oldukları toplumun geleneksel inançları veya kültürün büyük bir etkisi olduğu sonucuna ulaşmışlardır. Araştırmada 300 öğrenciye sordukları meslek tercihleri sonucunda kız çocuklarının daha narin işleri seçtiği, erkek çocuklarının ise daha zor ve güç gerektiren işler seçtiği tespit edilmiştir. Heredia (2007) çocukların üniversiteye başlamadan önce kariyer seçimlerinde cinsiyet kalıpyargılarına sahip olduğunu belirtmiştir. Ramaci ve arkadaşlarının (2017) ve Shapiro ve Williams (2012)'ın yaptıkları çalışmada da erkeklerin çoğunlukla bilim ve ticaret ile ilgili meslekleri tercih ederken, kız çocuklarının öğretmenlik ve hemşirelik gibi sosyal ve sanatsal meslekleri tercih ettiği sonucuna ulaşılmıştır. Van der Vleuten ve arkadaşları (2016)'nın çalışma sonucunda erkek çocuklarının meslek seçimlerinde cinsiyet kalıpyargılarının kız çocuklarına oranla daha katı ve geleneksel olduklarını tespit etmiştir. Carole (2011)'nin yapmış olduğu çalışmada okul öncesi dönem çocuklarının meslek seçimlerinde toplumsal cinsiyet algıları ortaya çıkartmaya çalışmıştır. Çalışma sonucunda 3-4 yaş aralığındaki çocuklarının sinema sanatçılığı, öğretmen, aşçı, kuaför mesleklerini daha fazla kadın mesleği olarak seçtiği; doktor, futbolcu, bilim insanı ve işçi mesleklerini ise erkek mesleği olarak seçtiği görülmüştür. Pehlivan ve Gökbulut (2015)'un yaratıcı drama yöntemi ile okul öncesi dönem çocuklarına meslek tanıtımları için yapmış oldukları deneysel çalışmada, bazı oturumlarda erkek ve kız çocuklarının özellikle meslekler konusunda farklı tercihlerinin olduğunu gözlemlemiştir. Atölyelerde erkek çocuklarının ev yapmak için uğraştıkları gözlemlenirken, kız çocuklarının ise daha çok ev eşyalarını oluşturdukları gözlemlenmiştir. Aynı zamanda erkeklerin atölyede tercih etmiş oldukları işlerin kız çocuklarına göre daha fazla güç gerektiren işlere yöneldikleri sonucuna ulaşılmıştır. Aynı çalışmada "büyüyünce ne olmak istersin?" sorusuna ise kız çocuklarının daha çok balerin, erkek çocuklarının ise doktor ve polis olmak istedikleri ortaya çıkmıştır. Yağan Güder (2014)'in okul öncesi dönemdeki çocukların toplumsal cinsiyet algılarını ortaya çıkartmak amacıyla yapmış olduğu araştırma sonucunda da, kız ve erkek çocuklarının meslekleri cinsiyetlerine göre eşleştirdiği görülmüştür. Araştırmada "meslekleri eşleyelim" etkinliği kapsamında çocuklarla yapılan görüşmeler doğrultusunda çoğunlukla pilot, 
astronot ve itfaiyeci gibi mesleklerinin erkekler, hemşire, dansçı ve fotoğrafçı gibi mesleklerin ise kadınlar tarafından yapılan meslekler olarak belirtmişlerdir. Aktın (2014)'ın okul öncesi dönem çocuklarının mesleklerin öğretilmesine yönelik gerçekleştirdiği durum çalışması doğrultusunda 6 okul öncesi dönem çocuğu ile çalışılmıştır. Çalışma kapsamında çocuklara "büyüyyünce ne olmak istiyorsun, neden istiyorsun?" sorusuna erkek çocukları astronot, otobüs şoförü ve itfaiyeci olmak istediklerini söylerken, kız çocuklarının hemşire, doktor ve anne olmak istediklerini söyledikleri görülmüştür. Mevcut çalışmaların bulguları incelendiğinde, çocukların meslek seçimlerinde bireyin toplumsal cinsiyet kalıpyargılarının önemli bir etkisinin olduğu sonucuna ulaşılmaktadır.

Bu araştırmanın amacı, okul öncesi kurumuna devam eden 36-72 aylık çocukların mesleklere karşı oluşturdukları toplumsal cinsiyet algılarının saptanmasıdır. Bu temel amaç doğrultusunda şu araştırma sorularına cevap aranmıştır:

1.Okul öncesi dönem çocukları doktor, polis, itfaiyeci, pilot, futbolcu, tamirci, iş makinası kullanıcısı, astronot, kaptan, öğretmen, hemşire, kabin görevlisi, aşçı, temizlik elemanı, terzi, spiker, şarkıc1, kasiyer mesleklerini hangi cinsiyete göre düşünmektedir?

2. Okul öncesi dönem çocuklarının mesleklere göre seçmiş oldukları cinsiyetlerin, çocuğun cinsiyeti, çocuğun yaşı, kaç yıldır anaokuluna devam ettiğgi, annenin öğrenim durumu ve yaşı, babanın öğrenim durumu ve yaşı, kardeş sayısı, çocuğun gittiği kurumda erkek öğretmenin var olup olmaması arasında anlamlı bir ilişki var mıdır?

\section{Yöntem}

\section{Araştırmanın Modeli}

$\mathrm{Bu}$ araştırma, nicel araştırma modeli ile tasarlanmıştır. Nicel araştırma modellerinden birisi olan betimsel tarama modelinden yararlanılmıştır. Karasar (2015)'a göre “betimsel tarama modelinde olan bir durumu ortaya çıkartmak, araştırmak ve belirlemek" amaçlanmaktadır. Bu çalışmada da çocukların mesleklere karşı oluşturdukları toplumsal cinsiyet kalıpyargılarını ortaya çıartmak amaçlandığı için betimsel tarama modeli seçilmiştir.

\section{Çalıșma Grubu}

$\mathrm{Bu}$ araştırmada çalışma grubunu, İstanbul ili Anadolu yakasında Milli Eğitim Bakanlığına bağlı özel ve devlet okul öncesi eğitim sınıflarında öğrenim görmekte olan 36-72 aylık toplam 200 çocuk oluşturmaktadır. Belirlenen okullar kolay ulaş1labilir örneklem yöntemi ile belirlenmiş olup, okullardan seçilen çocuklar ise rastgele örnekleme yöntemine göre belirlenmiştir. Araştırmaya dahil edilen okul öncesi dönem çocuklarının demografik bilgileri Tablo 1'de verilmiştir. 


\begin{tabular}{|c|c|c|c|}
\hline Demografik Bilgiler & & $\bar{n}$ & $\%$ \\
\hline Cinsiyet & $\begin{array}{c}\text { K1z } \\
\text { Erkek }\end{array}$ & $\begin{array}{l}100 \\
100\end{array}$ & $\begin{array}{l}50,0 \\
50,0\end{array}$ \\
\hline Yaş & $\begin{array}{l}36-48 \text { aylık } \\
49-60 \text { aylık } \\
61-72 \text { aylık }\end{array}$ & $\begin{array}{l}66 \\
68 \\
66 \\
\end{array}$ & $\begin{array}{l}33,0 \\
34,0 \\
33,0 \\
\end{array}$ \\
\hline Anne Öğrenim Durumu & $\begin{array}{c}\text { Ortaokul ve altı } \\
\text { Lise } \\
\text { Üniversite }\end{array}$ & $\begin{array}{c}33 \\
60 \\
107\end{array}$ & $\begin{array}{l}16,5 \\
30,0 \\
53,5\end{array}$ \\
\hline Baba Öğrenim Durumu & $\begin{array}{c}\text { Ortaokul ve altı } \\
\text { Lise } \\
\text { Üniversite }\end{array}$ & $\begin{array}{c}20 \\
74 \\
106 \\
\end{array}$ & $\begin{array}{l}10,0 \\
37,0 \\
53,0\end{array}$ \\
\hline $\begin{array}{c}\text { Okul Öncesine Devam Etme } \\
\text { Süresi } \\
\end{array}$ & $\begin{array}{c}0-12 \text { ay } \\
13 \text { ay ve üstü }\end{array}$ & $\begin{array}{c}160 \\
40 \\
\end{array}$ & $\begin{array}{l}80,0 \\
20,0 \\
\end{array}$ \\
\hline Kardeş Sayısı & $\begin{array}{l}\text { Tek Çocuk } \\
\text { İki Çocuk } \\
\text { Üç ve Üzeri }\end{array}$ & $\begin{array}{l}80 \\
95 \\
25\end{array}$ & $\begin{array}{l}40,0 \\
47,5 \\
12,5\end{array}$ \\
\hline Anne Yaş & $\begin{array}{c}30 \text { yaş ve altı } \\
31-35 \text { yaş } \\
36-40 \text { yaş } \\
41 \text { yaș ve üstü }\end{array}$ & $\begin{array}{l}38 \\
65 \\
57 \\
40\end{array}$ & $\begin{array}{l}19,0 \\
32,5 \\
28,5 \\
20,0 \\
\end{array}$ \\
\hline Baba Yaş & $\begin{array}{c}30 \text { yaş ve alt1 } \\
31-35 \text { yaş } \\
36-40 \text { yaş } \\
41 \text { yaş ve üstü }\end{array}$ & $\begin{array}{l}16 \\
45 \\
68 \\
71\end{array}$ & $\begin{array}{c}8,0 \\
22,5 \\
34,0 \\
35,5\end{array}$ \\
\hline $\begin{array}{c}\text { Okulda Erkek Öğretmen } \\
\text { Bulunma Durumu }\end{array}$ & $\begin{array}{c}\text { Var } \\
\text { Yok } \\
\end{array}$ & $\begin{array}{c}135 \\
65 \\
200\end{array}$ & $\begin{array}{l}67,5 \\
32,5 \\
100\end{array}$ \\
\hline
\end{tabular}

Tablo 1 incelendiğinde, araştırmaya katılan okul öncesi çocuklarının \%50'sinin kız, \%50'sinin erkek olduğu sonucuna ulaşılmıştır. Araştırmaya katılan çocukların \%33'ünün 36-48 aylık, \%34'ünün 49-60 aylık ve \%33'ünün 61-72 aylık olduğu tespit edilmiştir. Anne ve baba öğrenim düzeyleri incelendiğinde ise; annelerin \%53,5'inin üniversite, \%30'unun lise ve \%16,5'inin ortaokul ve alt1; babaların \%53'ünün üniversite, \%37'sinin lise ve \%10'unun ise ortaokul ve alt1 öğrenim düzeyine sahip oldukları belirlenmiştir. Çocukların \%80'inin 0-12 aydır, \%20'sinin 13 ay ve üstü süredir okul öncesi eğitime devam ettiği görülmüştür. Kardeş sayısı değişkeni incelendiğinde ise araştırmaya katılan çocukların \%47,5'inin iki kardeş, \%40'ının kardeşinin olmadığı ve \%12,5'inin ise üç ve üzeri kardeş sayısına sahip olduğu tespit edilmiştir. Çalışma grubundaki çocukların anne yaşı yoğunlukla 31-35 yaş arasında olduğu görülürken, baba yaşlarının ise 41 yaş ve üzerinde yoğunlaştığı görülmektedir. Çocukların \%67,5'inin okullarında erkek öğretmen mevcut iken, \%32,5'inin okulunda ise erkek öğretmenin bulunmadığı saptanmıştır.

\section{Veri Toplama Araçları}

Araştırmada, araştırmacıların geliştirdiği yapılandırılmış "Bu Mesleği Kim Yapar Formu", meslekleri yapan kişilerin kullandıkları araçların bulunduğu 18 adet resim kartı ve üzerinde sadece kadın, sadece erkek ve hem kadın hem erkek resimlerinin bulunduğu resim kartları kullanılmıştır.

\section{Bu Mesleği Kim Yapar Formu}

Araştırmacılar tarafından hazırlanan "Bu Mesleği Kim Yapar Formu"nda, çocukların cinsiyeti, yaşı, anaokuluna devam etme süreleri, anne öğrenim durumu ve yaşı, baba öğrenim durumu ve yaşı, kardeş sayısı, kurumda erkek öğretmen bulunma durumlarını içeren toplam 9 kapalı uçlu soru bulunmaktadır. Ayrıca çocuğa gösterilen resimli kartlar doğrultusunda seçtiği sadece kadın/ 
sadece erkek/ hem kadın hem erkek seçeneklerinin araştırmacı tarafından işaretlemesini sağlayan kısımlara da bu form üzerinde yer verilmiştir.

\section{Resimli Kartlar}

Doktor, polis, itfaiyeci, pilot, futbolcu, tamirci, iș makinası kullanıcısı, astronot, kaptan, öğretmen, hemşire, kabin görevlisi, aşçı, temizlik elemanı, terzi, spiker, şarkıcı, kasiyer mesleklerini yapan kişilerin kullandıkları, bu meslekleri tanımlayıcı araçların bulunduğu 18 adet resim kartı ve sadece kadın, sadece erkek ve hem kadın hem erkek resimlerinin bulunduğu resim kartlar araştırmada veri toplama aracı olarak kullanılmıştır. Örnek resimler aşağıda Resim 1 ve Resim 2 de verilmiştir.

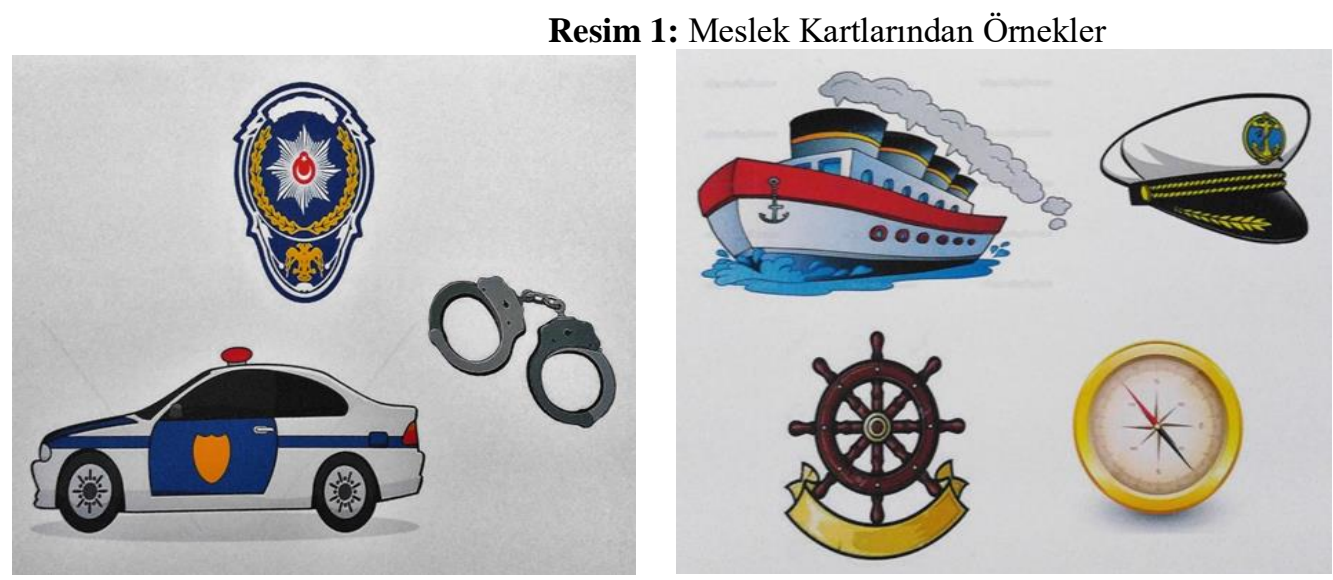

Resim 2: Meslek Kartlarından Örnekler

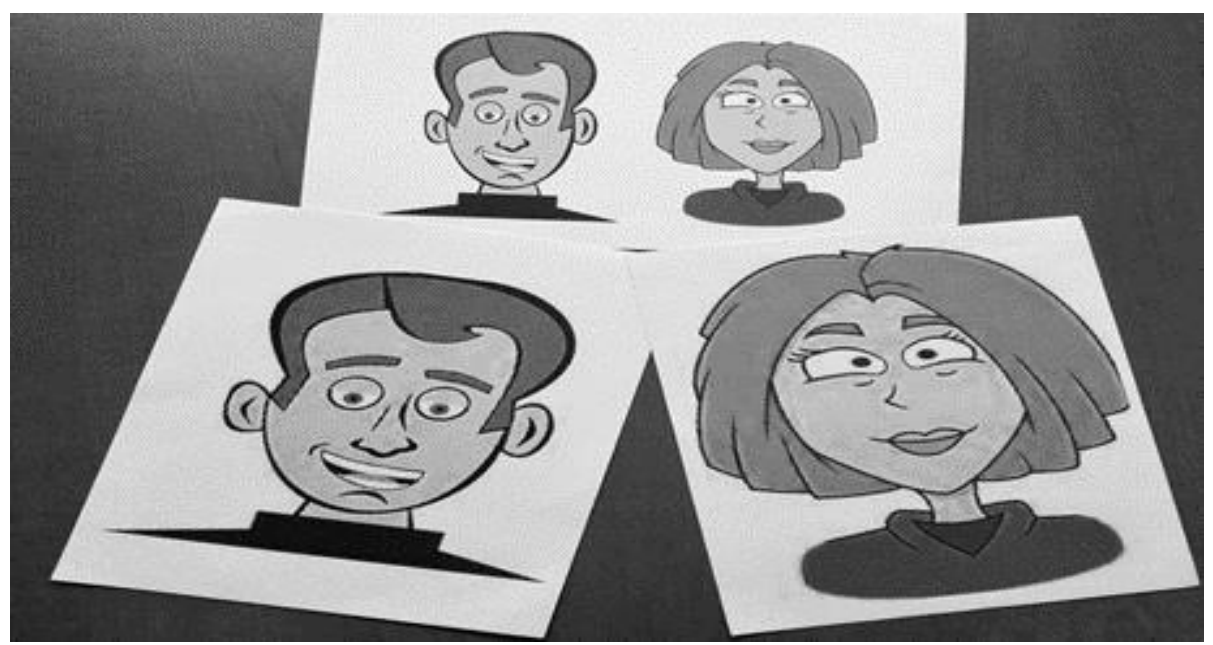

\section{Veri Toplama Süreci}

Araştırmacılar olarak öncelikle alanyazın taraması yaparak çocukların en çok tercih ettikleri meslek alanları belirlemeyi hedeflemiştir. Meslek alanları belirlendikten sonra o meslek alanları ile ilgili materyallerin resimleri internet üzerinden bulunmuştur. Ayrıca sadece kadın, sadece erkek ve hem kadın hem erkek resimleri de ayrıca internet üzerinden aranmıştır. Uygun resimler bulunduktan sonra 5 çocuk gelişimi/okul öncesi eğitim alanında en az yüksek lisans mezunu alan uzmanlarına resimler gönderilip, resimler hakkında uzman görüşleri alınmıştır. Gelişim düzeylerine ve mesleklere dair resimlerin uygunluğunda en az \%80 uzman görüş uyumu aranmıştır. Bu araştırmada araştırmacı arası tutarlıklar hesaplanmış ve uyum yüzdesi \%90 olarak bulunmuştur. Uzman görüşleri doğrultusunda gerekli düzenlemeler yapılarak resimli kartlar son halini almıştır. Ardından 
araştırmacılar tarafından gerekli izinler alınmıştır. Araştırma çocuklarla bireysel görüşme tekniği kullanılarak yapılmıştır. Çocuklarla yapılan görüşmeler doğrultusunda her birine standart bir yönerge sunulmuştur. Bu yönerge: 'Şimdi sana üzerinde resimler olan kartlar göstereceğim. Bu resimlerde bazı meslekleri yapan insanların kullandıkları eşyalar var. Bu resimlere dikkatlice bakıp, bana önce bu mesleğin adını daha sonra bu mesleği yapan kişilerin kadın mi, erkek mi ya da hem kadın hem erkek mi yapıyor söyler misin? şeklindedir. Çocuğun ilgili mesleği hangi cinsiyetin yaptığına dair vermiş olduğu yanıtlar "Bu Mesleği Kim Yapar Formu”na araştırmacılar tarafindan kaydedilmiştir. Her bir çocukla yapılan uygulama süresi ortalama 7 ile 10 dakika arasındadır. Uygulamalar her çocuğun kendi eğitim gördüğü okulda ve serbest zaman süresinde yapılmıştır.

\section{Verilerin Analizi}

Veri analizinde yüzde, frekans analizlerinden ve ki-kare testinden yararlanılmıştır. Bu aşamada SPSS 21.0 programından yararlanılmıştır.

\section{Bulgular}

\section{Okulöncesi Dönem Çocukları Meslekleri Hangi Cinsiyete Özgü Düşünmektedir?}

Çalışmaya katılan çocuklara gösterilen resimler doğrultusunda hangi mesleği hangi cinsiyetten bireylerle eşleştirdiğine dair yüzde ve frekans analizi Tablo 2'de verilmiştir.

Tablo 2: Mesleklere Yönelik Çocukların Cevapları

\begin{tabular}{lcccccc}
\hline \multirow{2}{*}{ Meslekler } & \multicolumn{2}{c}{ Sadece Kadınlar } & \multicolumn{2}{c}{ Sadece Erkekler } & \multicolumn{2}{c}{ Hem Kadın Hem Erkek } \\
\cline { 2 - 7 } & $\mathbf{n}$ & $\mathbf{\%}$ & $\mathbf{n}$ & $\mathbf{\%}$ & $\mathbf{n}$ & $\mathbf{\%}$ \\
\hline Doktor & 31 & 15,5 & 72 & 36,0 & 97 & $\mathbf{4 8 , 5}$ \\
\hline Polis & 11 & 5,5 & 129 & $\mathbf{6 4 , 5}$ & 60 & 30,0 \\
\hline İtfaiyeci & 20 & 10,0 & 133 & $\mathbf{6 6 , 5}$ & 47 & 23,5 \\
\hline Pilot & 24 & 12,0 & 135 & $\mathbf{6 7 , 5}$ & 41 & 20,5 \\
\hline Futbolcu & 9 & 4,5 & 147 & $\mathbf{7 3 , 5}$ & 44 & 22,0 \\
\hline Tamirci & 7 & 3,5 & 175 & $\mathbf{8 7 , 5}$ & 18 & 9,0 \\
\hline İş Makinesi Kullanıcısı & 13 & 6,5 & 166 & $\mathbf{8 3 , 0}$ & 21 & 10,5 \\
\hline Astronot & 11 & 5,5 & 129 & $\mathbf{6 4 , 5}$ & 60 & 30,0 \\
\hline Kaptan & 9 & 4,5 & 153 & $\mathbf{7 6 , 5}$ & 38 & 19,0 \\
\hline Öğretmen & 95 & $\mathbf{4 7 , 5}$ & 11 & 5,5 & 94 & 47,0 \\
\hline Hemşire & 120 & $\mathbf{6 0 , 0}$ & 40 & 20,0 & 40 & 20,0 \\
\hline Kabin Görevlisi & 61 & 30,5 & 73 & $\mathbf{3 6 , 5}$ & 66 & 33,0 \\
\hline Aşçı & 79 & $\mathbf{3 9 , 5}$ & 56 & 28,0 & 65 & 32,5 \\
\hline Temizlik Elemanı & 83 & $\mathbf{4 1 , 5}$ & 63 & 31,5 & 54 & 27,0 \\
\hline Terzi & 106 & $\mathbf{5 3 , 0}$ & 46 & 23,0 & 48 & 24,0 \\
\hline Spiker & 22 & 11,0 & 98 & $\mathbf{4 9 , 0}$ & 80 & 40,0 \\
\hline Şarkıcı & 26 & 13,0 & 95 & $\mathbf{4 7 , 5}$ & 79 & 39,5 \\
\hline Kasiyer & 56 & 28,0 & 39 & 19,5 & 105 & $\mathbf{5 2 , 5}$ \\
\hline
\end{tabular}

Tablo 2 incelendiğinde, çocukların yüksek oranda sadece kadınlara özgü olarak düşündükleri mesleklerin sırasıyla Hemşire (\%60), Terzi (\%53), Öğretmen (\%47,5), Aşç1 (\%39,5), Temizlik Elemanı $(\% 41,5)$; erkeklere özgü düşündükleri mesleklerin sırasıyla Tamirci $(\% 87,5)$, İş Makinesi Kullanıcisı $(\% 83,0)$, Kaptan $(\% 76,5)$, Futbolcu $(\% 73,5)$, Pilot $(\% 67,5)$, İtfaiyeci $(\% 66,5)$, Polis $(\% 64,5)$, Spiker $(\% 49,0)$, Şarkıcı $(\% 47,5)$ ve Kabin Görevlisi $(\% 36,5)$; hem kadın hem erkek için düşündükleri mesleklerin ise sırayla Kasiyer $(\% 52,5)$ ve Doktor $(\% 48,5)$ olduğu görülmektedir. Tablo 2'den çıkan bir diğer bulgu ise çocukların bu 18 meslekten sadece 5 tanesini yoğun olarak kadınlara özgü olarak seçerken, 10 tanesini yoğun olarak erkeklere özgü seçmektedir. Erkeklere yönelik meslek algılarının kadınlara yönelik meslek algısından oldukça fazla olduğu görülmektedir. 


\section{Okul Öncesi Dönem Çocuklarının Mesleklere Göre Seçmiş Oldukları Cinsiyetlerin,} Çocuğun Farklı Değişkenleri Arasında Anlamı Bir İlişki Var Mıdır?

Çalışma grubuna alınan okul öncesi dönem çocuklarının farklı değişkenleri ile meslek kartları için seçmiş oldukları cinsiyetler arasında anlamlı bir ilişkinin olup olmadığını tespit etmek amacıyla Ki-Kare analizi yapılmıştır. Yapılan analiz sonucunda çocukların cinsiyetleri, okul öncesi eğitim kurumuna devam etme süresi ve kardeş sayısı değişkeni ile mesleklere dair seçmiş oldukları cinsiyet türleri arasında anlamlı bir ilişkiye rastlanmamıştır.

Çocukların yaş bağımsız değişkenleri ile mesleklere dair seçmiş olduğu cinsiyet türleri arasında anlamlı ilişkilere rastlanmıştır. Yapılan Ki-Kare analiz sonuçları Tablo 3'te verilmiştir.

Tablo 3: Yaş Değişkeni ile Mesleklere Dair Cinsiyet Algıları

\begin{tabular}{|c|c|c|c|c|c|c|c|}
\hline & \multicolumn{6}{|c|}{ Yaş } & \multirow{3}{*}{$\mathrm{X}^{2 \text { Sonuçlar }}$} \\
\hline & \multicolumn{2}{|c|}{ 36-48 Aylık } & \multicolumn{2}{|c|}{ 49-60 Aylık } & \multicolumn{2}{|c|}{ 61-72 Aylık } & \\
\hline & $\mathrm{n}$ & $\%$ & $\mathrm{n}$ & $\%$ & $\mathrm{n}$ & $\%$ & \\
\hline Doktor & & & & & & & $X^{2}: 14,575$ \\
\hline Sadece Kadın & 13 & 19,7 & 8 & 11,8 & 10 & 15,2 & $\mathrm{Sd}: 4$ \\
\hline Sadece Erkek & 33 & 50,0 & 23 & 33,8 & 16 & 24,2 & $\mathrm{p}:, 006^{*}$ \\
\hline Hem Kadın Hem Erkek & 20 & 30,3 & 37 & 54,4 & 40 & 60,6 & \\
\hline İtfaiyeci & & & & & & & $\mathrm{X}^{2}: 10,481$ \\
\hline Sadece Kadın & 11 & 16,7 & 7 & 10,3 & 2 & 3,0 & $\mathrm{Sd}: 4$ \\
\hline Sadece Erkek & 43 & 65,2 & 48 & 70,6 & 42 & 63,6 & p:, $033^{*}$ \\
\hline Hem Kadın Hem Erkek & 12 & 18,2 & 13 & 19,1 & 22 & 33,3 & \\
\hline Öğretmen & & & & & & & $\mathrm{X}^{2}: 17,907$ \\
\hline Sadece Kadın & 44 & 66,7 & 29 & 42,6 & 22 & 33,3 & Sd: 4 \\
\hline Sadece Erkek & 4 & 6,1 & 2 & 2,9 & 5 & 7,6 & p:, $001^{*}$ \\
\hline Hem Kadın Hem Erkek & 18 & 27,3 & 37 & 54,4 & 39 & 59,1 & \\
\hline Hemşire & & & & & & & $X^{2}: 22,365$ \\
\hline Sadece Kadın & 36 & 54,5 & 43 & 63,2 & 41 & 62,1 & $\mathrm{Sd}: 4$ \\
\hline Sadece Erkek & 24 & 36,4 & 11 & 16,2 & 5 & 7,6 & $\mathrm{p}:, 000^{*}$ \\
\hline Hem Kadın Hem Erkek & 6 & 9,1 & 14 & 20,6 & 20 & 30,3 & \\
\hline Aş̧̧ı & & & & & & & $X^{2}: 15,532$ \\
\hline Sadece Kadın & 37 & 56,1 & 26 & 38,2 & 16 & 24,2 & $\mathrm{Sd}: 4$ \\
\hline Sadece Erkek & 15 & 22,7 & 21 & 30,9 & 20 & 30,3 & p:, $004 *$ \\
\hline Hem Kadın Hem Erkek & 14 & 21,2 & 21 & 30,9 & 30 & 45,5 & \\
\hline Terzi & & & & & & & $\mathrm{X}^{2}: 10,237$ \\
\hline Sadece Kadın & 38 & 57,6 & 39 & 57,4 & 29 & 43,9 & Sd: 4 \\
\hline Sadece Erkek & 19 & 28,8 & 14 & 20,6 & 13 & 19,7 & p:, $037^{*}$ \\
\hline Hem Kadın Hem Erkek & 9 & 13,6 & 15 & 22,1 & 24 & 36,4 & \\
\hline Spiker & & & & & & & $X^{2}: 15,000$ \\
\hline Sadece Kadın & 12 & 18,2 & 4 & 5,9 & 6 & 9,1 & $\mathrm{Sd}: 4$ \\
\hline Sadece Erkek & 37 & 56,1 & 37 & 54,4 & 24 & 36,4 & $\mathrm{p}:, 005^{*}$ \\
\hline Hem Kadın Hem Erkek & 17 & 25,8 & 27 & 39,7 & 36 & 54,6 & \\
\hline Şarkıcı & & & & & & & \\
\hline Sadece Kadın & 14 & 21,2 & 6 & 8,8 & 6 & 9,1 & $X^{2}: 9,788$ \\
\hline Sadece Erkek & 33 & 50,0 & 35 & 51,5 & 27 & 40,9 & $\mathrm{Sd}: 4$ \\
\hline Hem Kadın Hem Erkek & 19 & 28,8 & 27 & 39,7 & 33 & 50,0 & $\mathrm{p}:, 044^{*}$ \\
\hline Kasiyer & & & & & & & $X^{2}: 22,602$ \\
\hline Sadece Kadın & 21 & 31,8 & 20 & 29,4 & 15 & 22,7 & Sd: 4 \\
\hline Sadece Erkek & 23 & 34,8 & 11 & 16,2 & 5 & 7,6 & $\mathrm{p}:, 000^{*}$ \\
\hline Hem Kadın Hem Erkek & 22 & 33,3 & 37 & 54,4 & 46 & 69,7 & \\
\hline
\end{tabular}


Tablo 3 incelendiğinde, çocukların yaş bağımsız değişkeni ile doktor, itfaiyeci, öğretmen, hemşire, aşçı, terzi, spiker, şarkıcı ve kasiyer mesleklerine dair cinsiyet algıları arasında anlamlı bir ilişkiye rastlanmıştır. Anlamlı ilişki incelendiğinde, çocukların yaşları büyüdükçe doktor, itfaiyeci, öğretmen, hemşire, aşçı, terzi, spiker, şarkıcı ve kasiyer mesleklerine dair cinsiyet kalıp yargılarının azaldığı ve bu meslekleri hem kadının hem de erkeğin yapabileceğine dair toplumsal cinsiyet eşitlikçi algının arttığı sonucuna ulaşılmıştır.

Çocukların baba ve anne öğrenim durumu bağımsız değişkenleri ile mesleklere dair seçmiş olduğu cinsiyet türleri arasında bazı anlamlı ilişkilere rastlanmıştır. Yapılan Ki-Kare analiz sonuçları Tablo 4-5'te verilmiştir.

Tablo 4: Baba Öğrenim Durumu Değişkeni ile Mesleklere Dair Cinsiyet Algıları

\begin{tabular}{|c|c|c|c|c|c|c|c|}
\hline & \multicolumn{6}{|c|}{ Baba Öğrenim } & \multirow{3}{*}{$\mathrm{X}^{2}$ Sonuçları } \\
\hline & \multicolumn{2}{|c|}{ Ortaokul ve altı } & \multicolumn{2}{|c|}{ Lise } & \multicolumn{2}{|c|}{ Üniversite } & \\
\hline & $\mathrm{n}$ & $\%$ & $\mathrm{n}$ & $\%$ & $\mathrm{n}$ & $\%$ & \\
\hline Pilot & & & & & & & $X^{2}: 16,646$ \\
\hline Sadece Kadın & 3 & 15,0 & 15 & 18,9 & 7 & 6,6 & Sd: 4 \\
\hline Sadece Erkek & 15 & 75,0 & 53 & 71,6 & 67 & 63,2 & $\mathrm{p}:, 002^{*}$ \\
\hline Hem Kadın Hem Erkek & 2 & 10,0 & 7 & 9,5 & 32 & 30,2 & \\
\hline
\end{tabular}

Tablo 5: Anne Öğrenim Durumu Değişkeni ile Mesleklere Dair Cinsiyet Algıları

\begin{tabular}{|c|c|c|c|c|c|c|c|}
\hline & \multicolumn{6}{|c|}{ Anne Öğrenim } & \multirow{3}{*}{$\mathrm{X}^{2 \text { Sonuçlar }}$} \\
\hline & \multicolumn{2}{|c|}{ Ortaokul ve altı } & \multicolumn{2}{|c|}{ Lise } & \multicolumn{2}{|c|}{ Üniversite } & \\
\hline & $\overline{\mathrm{n}}$ & $\%$ & $\mathrm{n}$ & $\%$ & $\mathrm{n}$ & $\%$ & \\
\hline Kabin Görevlisi & & & & & & & $\mathrm{X}^{2}: 14,604$ \\
\hline Sadece Kadın & 3 & 9,1 & 21 & 35,0 & 37 & 34,6 & Sd: 4 \\
\hline Sadece Erkek & 21 & 63,9 & 20 & 33,3 & 32 & 29,9 & $\mathrm{p}:, 006^{*}$ \\
\hline Hem Kadın Hem Erkek & 9 & 27,3 & 19 & 31,7 & 38 & 35,5 & \\
\hline Temizlik Elemanı & & & & & & & \\
\hline Sadece Kadın & 12 & 36,4 & 22 & 36,7 & 49 & 45,8 & $X^{2}: 12,135$ \\
\hline Sadece Erkek & 17 & 51,5 & 22 & 36,7 & 24 & 22,4 & Sd: 4 \\
\hline Hem Kadın Hem Erkek & 4 & 12,1 & 16 & 26,7 & 34 & 31,8 & p:, $016^{*}$ \\
\hline
\end{tabular}

Tablo 4 incelendiğinde, çocukların baba öğrenim düzeyleri ile çocukların sadece pilot mesleğine dair cinsiyet algılarında anlamlı bir ilişkiye rastlanmaktadır. Tablo 5 'te ise anne öğrenim düzeyi ile çocukların kabin görevlisi ve temizlik elemanı mesleklerine dair cinsiyet algıları arasında anlamlı bir ilişki tespit edilmiştir. Hem anne hem de baba öğrenim düzeyi arttıkça pilot, kabin görevlisi ve temizlik elemanı mesleklerine dair cinsiyet kalıp yargılarının azaldığ 1 ve bu meslekleri hem kadının hem de erkeğin yapabileceğine dair toplumsal cinsiyet eşitlikçi algının arttığı sonucuna ulaşılmıştır.

Çocukların anne ve baba yaş bağımsız değişkenleri ile mesleklere dair seçmiş olduğu cinsiyet türleri arasında bazı anlamlı ilişkilere rastlanmıştır. Yapılan Ki-Kare analiz sonuçları Tablo 6-7'de verilmiştir. 
Tablo 6: Anne Öğrenim Durumu Değişkeni ile Mesleklere Dair Cinsiyet Algıları

\begin{tabular}{|c|c|c|c|c|c|c|c|c|c|}
\hline & \multicolumn{8}{|c|}{ Anne Yaş } & \multirow{3}{*}{$\mathrm{X}^{2 \text { Sonuçları }}$} \\
\hline & \multicolumn{2}{|c|}{30 yaş ve altı } & \multicolumn{2}{|c|}{ 31-35 yaş } & \multicolumn{2}{|c|}{ 36-40 yaș } & \multicolumn{2}{|c|}{41 ve üstü } & \\
\hline & $\mathrm{n}$ & $\%$ & $\mathrm{n}$ & $\%$ & $\mathrm{n}$ & $\%$ & $\mathrm{n}$ & $\%$ & \\
\hline Aşçı & & & & & & & & & $X^{2}: 1,912$ \\
\hline Sadece Kadın & 21 & 55,3 & 24 & 36,9 & 23 & 40,4 & 11 & 27,4 & Sd: 6 \\
\hline Sadece Erkek & 12 & 31,6 & 24 & 36,9 & 10 & 17,5 & 10 & 25,0 & $\mathrm{p}:, 006^{*}$ \\
\hline Hem Kadın Hem Erkek & 5 & 13,2 & 17 & 26,2 & 24 & 42,1 & 19 & 47,5 & \\
\hline Şarkıcı & & & & & & & & & $\mathrm{X}^{2}: 19,325$ \\
\hline Sadece Kadın & 7 & 18,4 & 13 & 20,0 & 5 & 8,8 & 1 & 2,5 & Sd: 6 \\
\hline Sadece Erkek & 24 & 63,2 & 28 & 43,1 & 28 & 49,1 & 15 & 37,5 & p:, $004 *$ \\
\hline Hem Kadın Hem Erkek & 7 & 18,4 & 24 & 36,9 & 24 & 42,1 & 240 & 60,0 & \\
\hline
\end{tabular}

Tablo 6 incelendiğinde, çocukların anne yaşları ile çocukların aşçı ve şarkıcı mesleğine dair cinsiyet algılarında anlamlı bir ilişkiye rastlanmaktadır. Anne yaş arttıkça çocuğun aşçı ve şarkıcı mesleklerine dair cinsiyet kalıp yargılarının azaldığı ve bu meslekleri hem kadının hem de erkeğin yapabileceğine dair toplumsal cinsiyet eşitlikçi algının arttığı sonucuna ulaşılmıştır.

Tablo 7: Anne Öğrenim Durumu Değişkeni ile Mesleklere Dair Cinsiyet Algıları

\begin{tabular}{|c|c|c|c|c|c|c|c|c|c|}
\hline & \multicolumn{8}{|c|}{ Baba Yaş } & \multirow{3}{*}{$\mathrm{X}^{2 \text { Sonuçları }}$} \\
\hline & \multicolumn{2}{|c|}{30 yaş ve altı } & \multicolumn{2}{|c|}{ 31-35 yaş } & \multicolumn{2}{|c|}{$36-40$ yaş } & \multicolumn{2}{|c|}{41 ve üstü } & \\
\hline & $\mathrm{n}$ & $\%$ & $\mathrm{n}$ & $\%$ & $\mathrm{n}$ & $\%$ & $\mathrm{n}$ & $\%$ & \\
\hline Aşçı & & & & & & & & & $X^{2}: 13,265$ \\
\hline Sadece Kadın & 9 & 56,3 & 23 & 51,1 & 27 & 39,7 & 20 & 28,2 & Sd: 6 \\
\hline Sadece Erkek & 3 & 18,8 & 13 & 28,9 & 22 & 32,4 & 18 & 25,4 & $\mathrm{p}:, 039 *$ \\
\hline Hem Kadın Hem Erkek & 4 & 25,0 & 9 & 20,0 & 19 & 27,9 & 33 & 46,5 & \\
\hline Şarkıcı & & & & & & & & & $X^{2}: 14,463$ \\
\hline Sadece Kadın & 1 & 6,3 & 7 & 15,6 & 13 & 19,1 & 5 & 7,0 & Sd: 6 \\
\hline Sadece Erkek & 11 & 68,8 & 27 & 60,0 & 26 & 38,2 & 31 & 43,7 & $\mathrm{p}:, 025^{*}$ \\
\hline Hem Kadın Hem Erkek & 4 & 25,0 & 11 & 24,4 & 29 & 42,6 & 35 & 49,3 & \\
\hline
\end{tabular}

Tablo 7 incelendiğinde, çocukların baba yaşları ile çocukların aşçı ve şarkıcı mesleğine dair cinsiyet algılarında anlamlı bir ilişkiye rastlanmaktadır. Baba yaş arttıkça çocuğun aşçı ve şarkıcı mesleklerine dair cinsiyet kalıp yargılarının azaldığı ve bu meslekleri hem kadının hem de erkeğin yapabileceğine dair toplumsal cinsiyet eşitlikçi algının arttığı sonucuna ulaşılmıştır.

Çocukların eğitim gördükleri kurumda erkek öğretmenin bulunma durumu bağımsız değiş̧keni ile mesleklere dair seçmiş olduğu cinsiyet türleri arasında anlamlı ilişkilere rastlanmıştır. Yapılan Ki-Kare analiz sonuçları Tablo 8'de sunulmuştur. 
Tablo 8: Kurumda Erkek Öğretmen Bulunma Durumu Değişkeni ile Mesleklere Dair Cinsiyet

\begin{tabular}{|c|c|c|c|c|c|}
\hline \multicolumn{6}{|c|}{ Algilar1 } \\
\hline & \multicolumn{4}{|c|}{ Kurumda Erkek Öğretmen } & \multirow{3}{*}{$\mathrm{X}^{2}$ Sonuçları } \\
\hline & \multirow{2}{*}{$\begin{array}{l}\text { Var } \\
\mathrm{n}\end{array}$} & & \multicolumn{2}{|c|}{ Yok } & \\
\hline & & $\%$ & $\mathrm{n}$ & $\%$ & \\
\hline Öğretmen & & & & & $\mathrm{X}^{2}: 25,101$ \\
\hline Sadece Kadın & 49 & 36,3 & 46 & 70,8 & Sd: 2 \\
\hline Sadece Erkek & 6 & 4,4 & 5 & 7,7 & $\mathrm{p}:, 000^{*}$ \\
\hline Hem Kadın Hem Erkek & 80 & 59,3 & 14 & 21,5 & \\
\hline Terzi & & & & & $X^{2}: 7,440$ \\
\hline Sadece Kadın & 65 & 48,1 & 41 & 63,1 & $\mathrm{Sd}: 2$ \\
\hline Sadece Erkek & 30 & 22,2 & 16 & 24,6 & p:, $024^{*}$ \\
\hline Hem Kadın Hem Erkek & 40 & 29,6 & 8 & 12,3 & \\
\hline Spiker & & & & & $\mathrm{X}^{2}: 8,058$ \\
\hline Sadece Kadın & 12 & 8,9 & 10 & 15,4 & Sd: 2 \\
\hline Sadece Erkek & 60 & 44,4 & 38 & 58,5 & $\mathrm{p}:, 018^{*}$ \\
\hline Hem Kadın Hem Erkek & 63 & 46,7 & 17 & 26,2 & \\
\hline Kasiyer & & & & & $X^{2}: 8,829$ \\
\hline Sadece Kadın & 35 & 25,9 & 21 & 32,3 & Sd: 2 \\
\hline Sadece Erkek & 20 & 14,8 & 19 & 29,2 & $\mathrm{p}:, 012^{*}$ \\
\hline Hem Kadın Hem Erkek & 80 & 59,3 & 25 & 38,5 & \\
\hline Doktor & & & & & $\mathrm{X}^{2}: 13,481$ \\
\hline Sadece Kadın & 20 & 14,8 & 11 & 16,9 & $\mathrm{Sd}: 2$ \\
\hline Sadece Erkek & 38 & 28,1 & 34 & 52,3 & $\mathrm{p}:, 001^{*}$ \\
\hline Hem Kadın Hem Erkek & 77 & 57,0 & 20 & 30,8 & \\
\hline
\end{tabular}

Tablo 8 incelendiğinde, çocukların eğitim görmüş olduğu kurumda erkek öğretmen bulunma durumları ile çocukların öğretmen, terzi, spiker, kasiyer ve doktor mesleklerine dair cinsiyet algılarında anlamlı bir ilişkiye rastlanmaktadır. Eğitim görmüş olduğu kurumda erkek öğretmenin bulunan çocukların bu mesleklere dair cinsiyet kalıp yargılarının azaldığı ve bu meslekleri hem kadının hem de erkeğin yapabileceğine dair toplumsal cinsiyet eşitlikçi algının arttığı sonucuna ulaşılmıştır. Fakat kurumda erkek öğretmen bulunmaması durumunda ise çocukların bu mesleklere dair cinsiyetçi algıları artmaktadır.

\section{Sonuç ve Tartıșma}

Okul öncesi kurumuna devam eden 36-72 aylık çocukların mesleklere karşı oluşturdukları toplumsal cinsiyet algılarının saptanması amacıyla yapılan bu araştırma sonucunda, çocukların yüksek bir oranı hemşire, terzi, öğretmen, aşçı, temizlik elemanı mesleklerini kadın cinsiyetine; tamirci, iş makinesi kullanıcısı, kaptan, futbolcu, pilot, itfaiyeci, polis, spiker, şarkıcı ve kabin görevlisi mesleklerini ise erkek cinsiyetine özgü meslekler olarak algıladıkları sonucuna varılmıştır. Samaras, Bonoti ve Christidou (2012) ilköğretim çocuklarına bilim insanı çizdirip, çocuklardaki bilim insanı kavramı üzerindeki kalıpyargıları belirlemeye çalıştıkları araştırma sonucunda, çocukların yarısından fazlasının bilim insanını erkek çizdiği sonucuna ulaşılmıştır. Ocak Karabay ve arkadaşları (2018)'nın 5 yaş çocuklarının toplumsal cinsiyet kalıpyargılarının anlaşılması üzerine yapılan çalışmada da mesleklere değinilmiştir. Toplam 91 çocukla gerçekleştirilen çalışma sonucunda çoğunlukla erkek mesleği olarak polis, şoför, pilot, mühendis, marangoz ve itfaiyeciyi seçerken, kadın mesleği olarak da hemşire, aşçı, dansçı ve temizlik görevlisini seçmişlerdir. Bu çalışmalar araştırmamızın bulguları ile benzerlik göstermektedir. Bu algının oluşmasının en önemli nedenlerinden birisi o meslek dalından o cinsiyette bir birey ile karşılaşmamasından kaynaklı olduğu düşünülebilir. Taşdemir Akkavak ve Sarıkaya Karabudak (2019) tarafından hastanede yatan çocuklarda hemşire algısını ortaya çıkartmaya çalıştıkları çalışmalarında da çoğu çocuğa hemşire denildiğinde, kadın cinsiyetinde hemşire tarif ettiklerini tespit etmişlerdir. Çocuklara nedenleri 
sorulduğunda ise büyük çoğunluğunun nedeninin erkek hemşire görmemesinden kaynaklı olduğu sonucuna ulaşıllmıştır. Alanyazın incelendiğinde erkek hemşirelerin sayısı ne kadarda artsa, gelişmiş ülkelerden Kanada, ABD, İngiltere gibi ülkelerde bile toplam hemşirelerin \%10'unun erkek hemşire olduğu görülmektedir (Dyck, Oliffe, Phinney ve Garrett, 2009). Aykaç (2012), ilköğretim öğrencilerine resimler çizdirerek öğretmen algılarını ortaya çıkartmaya çalıştığ çalışmasında da benzer sonuçlara rastlanmaktadır. Farklı illerden toplam 1000 öğrenci ile yapılan çalışma sonucunda, öğrencilerin çizdikleri öğretmen figürünün \%62,4'ü kadın; \%31'inin ise erkek olduğu görülmüştür. Samaras, Bonoti ve Christidou (2012) ilköğretim çocuklarına bilim insanı çizdirip, çocuklardaki bilim insanı kavramı üzerindeki kalıpyargıları belirlemeye çalıştıkları araştırma sonucunda, çocukların yarısından fazlasının bilim insanını erkek çizdiği sonucuna ulaşılmışıı. Cansever Arslan (2017), 66-68 aylık çocukların çizimlerinden öğretmen kavramlarını ortaya çıkarmak amacıyla yapmış olduğu araştırma sonucunda, çocukların çizdikleri öğretmenlerin çoğunun kadın, neşeli, temiz ve bakımlı olarak resmettikleri görülmüştür. Ahi, Cingi ve Kıldan (2016) tarafindan 48-60 aylık çocukların öğretmen kavramına dair algılarını ortaya çıkartmak amacıyla yapmış oldukları çalışmada, çocukların sadece \%13,1'i öğretmeni erkek olarak resmetmiştir. Millî Eğitim Bakanlığ1 2016-2017 eğitim-öğretim y1lı kapsamında kamu ve özel sektörde çalışan okul öncesi öğretmen sayılarının istatistiklerini yayımlamıştır. $\mathrm{Bu}$ istatistiklere göre kadın öğretmenlerinin sayısının 72352, erkek öğretmenlerin sayısının ise 4032 olduğu görülmektedir (Haskan Avc1, Karababa ve Zencir, 2018). Bir diğer ifade ile Türkiye'de hem özel hem de kamu sektöründe çalışan okul öncesi öğretmenlerinin sadece \%5,6'sının erkektir. Bu nedenle okul öncesi öğretmenlerinin çoğunun erkek okul öncesi öğretmeni görmediği için öğretmen algısının kadın olduğu söylenebilir. Bu bulgunun bir diğer nedeni ise çocuğun izlediği veya okuduğu medya araçlarında bu durumu gözlemlediği için, çocukta meslekleri cinsiyetleştirdiği söylenebilir. Somer ve Değirmenci (2015) tarafından çocuklara özgü oluşturulmuș olan resimli çocuk kitaplarını toplumsal cinsiyet kavramı açısından analiz etmişlerdir. Araştırmanın bir boyutu da kitaplardaki mesleklerin icra eden karakterlerin cinsiyetinin belirlenmesidir. Kitaplarda kadın karakterlere dair mesleklerin yoğunlukla öğretmen ve hemşire; erkek karakterlere dair mesleklerin ise çoğunlukla yönetici-patron olduğu tespit edilmiştir. Kaynak ve Aktaş (2017)'in okul öncesi hikaye ve masal kitaplarındaki toplumsal cinsiyet rolleri üzerine yapmış olduğu çalışmasında da; mesleki açıdan karakterler incelendiğinde; kadınların en yüksek oranda öğretmen; erkeklerin ise en yüksek oranda esnaf olarak sunulduğu görülmüştür. Kitaplarda bulunan meslekler ve toplumsal cinsiyet kavramına ilişkin farklı çalışmada da benzer sonuçlara ulaşılmaktadır (Altan Arslan, 2000; Vatandaş, 2007). Günaydın (2011)'nın çocuklar için hazırlanmış olan televizyon programlarını toplumsal cinsiyet bağlamında incelediği çalışmasında, toplumsal cinsiyet eşitsizliği açısından çizgi filmlerde en belirgin durumun meslek durumları olduğu saptanmıştır. Özellikle erkek karakterlerin daha çok parayı, otoriteyi ve iktidarı temsil eden meslekleri icra ederken gösterildiği; kadın karakterlerin ise yardımcı rollerde çalıştırıldığı veya ev kadını rolünde olduğu gözlemlenmiştir. Özellikle çizgi filmlerdeki toplumsal cinsiyet eşitsizliği üzerine benzer bulgulara rastlanan çalışmalar bulunmaktadır (Thompson ve Zerbinos, 1995; Gökçearslan, 2010; Wiersma, 2000; Perea, 2018).

Araştırmanın bir diğer sonucu ise anne ve baba yaş ve öğrenim düzeyi arttıkça birçok mesleğe dair cinsiyet eşitsizliğini destekleyen kalıp yargılarının azaldığı ve bu meslekleri hem kadının hem de erkeğin yapabileceğine dair toplumsal cinsiyet eşitlikçi algının arttığı sonucuna ulaşılmıştır. Bu durum, anne ve babanın eğitim düzeyi arttıkça anne ve babanın bu konu hakkındaki bilinç düzeyinin yükselmesinden ve çocukların ise toplumsal cinsiyet konusunda bilinç düzeyi yüksek ebeveynleri gözlemleyerek ebeveynlerini rol model almasından kaynaklı olduğu düşünülebilir. Kuzlak, Çuvaş ve Sakallı-Uğurlu (2017) tarafından anne babaların eğitim ve mesleki statü durumlarının çocuklarının cinsiyetçilik düzeylerini etkileyip etkilemediğini belirlemek amacıyla yapmış oldukları çalışma sonucunda, özellikle anne eğitim düzeyi ve mesleki statüsü arttıkça, çocuklarının düşmanca cinsiyetçilik ve korumacı cinsiyetçilik puanlarının azaldığı sonucuna ulaşılmışıır. Varol, Çiçeklioğlu ve Taner (2016), Aylaz ve arkadaşları (2014), Pınar, Taşkın ve 
Eroğlu (2008), Altuntaş ve Altınova, (2015), Kalaycı ve Hayırsever (2014) ve Kodan Çetinkaya (2013) tarafından yapılan araştırmalarda da anne ve baba öğrenim düzeyi arttıkça çocukların toplumsal cinsiyet kalıp yargılarının azaldığı ve toplumsal cinsiyet eşitliği algısının yükseldiği tespit edilmiştir.

Çocukların yaşları yükseldikçe toplumsal cinsiyet eşitsizliğinin azaldığı çalışma sonucunda bulunmuştur. Bunun nedeni, özellikle 3-4 yaş grubundaki çocukların toplumsal cinsiyet görüşlerinin daha katı olmasından kaynaklandığı söylenebilir. Halim, Ruble, Tamis-LeMonda ve Shrout (2013), Ruble ve arkadaşları (2007) ve Yağan Güder (2014)'in çalışmaları incelendiğinde, özellikle 36-48 aylık çocuklarda daha katı ve değişmez bir toplumsal cinsiyet görüşüne sahipken, 60 aylıktan sonra bu katılığın azaldığg sonucuna varılmıştır.

Araştırmanın önemli ve son bulgusu ise okullarında erkek okul öncesi öğretmeni olan çocukların bazı mesleklere dair toplumsal cinsiyet eşitliğini destekleyen algıların arttı̆̆ gözlemlenmektedir. $\mathrm{Bu}$ durumun, çocukların toplum tarafından cinsiyetçi olarak tanımlanan mesleklerde çalışan karşı cinsten bir çalışan bireyi görmeleri sonucunda bu meslek alanına dair eşitlikçi bir algı oluşturabilmesinden kaynaklı olduğu düşünülebilir. Yağan Güder (2014)'in okul öncesi dönemdeki çocukların toplumsal cinsiyet algılarını belirlemek için yapmış olduğu araştırmada, çocuklardan bazıları sosyal çevresinde veya televizyonda o meslek çalışanlarını gördüğünde mesleklere ilişkin algılarının etkilenebileceği sonucuna ulaşmıştır. Çalışmada bazı çocuklar kadın inşaatçı olabileceğini ve bunun nedenini izledikleri çizgi filmde olmasından kaynaklı olduğunu söylemiştir. Bir diğer çocuk ise kadın otobüs şoför gördüğü için kadınlarında otobüs şoförü olabileceğini belirtmiştir.

Çalışma kapsamında aşağıdaki önerilerde bulunulabilir:

- Çocukların meslekler üzerinde cinsiyet eşitsizliklerini azaltmak veya ortadan kaldırmak amacı ile her mesleğin her iki cinsiyetinde yaptığı resimler veya her iki cinsiyetinde gerçekleştirdiği kahramanların bulunduğu hikaye kitapları, hikaye kartları oluşturulup çocuğa sunulabilir.

- Çalışmada anne ve baba yaşı arttıkça çocukların mesleklere dair kalıp yargılarının bazı mesleklere göre azaldığı görülmektedir. Bu kapsamda genç anne babalara toplumsal cinsiyet eşitliği ile ilgili eğitimler veya seminerler düzenlenebilir.

- Okullarında erkek okul öncesi öğretmenlerinin olması çocukların birçok mesleğe karş1 toplumsal cinsiyet anlamında eşitlikçi algılarının arttığı saptanmıştır. Bu kapsamda erkek okul öncesi öğretmen sayısının arttırılması için politikalar geliştirilebilir. Her okul öncesi eğitim kurumunda erkek okul öncesi öğretmenlerine yer verilebilir.

- Çalışmaya katılan çocukların anne ve babalarının öğrenim durumları da çocukların mesleklere karşı cinsiyet algısını etkilediği görülmüştür. Özellikle üst öğrenim düzeyine sahip olan ebeveynlerin çocuklarının, daha düşük öğrenime sahip olan ebeveynlerin çocuklarına oranla meslek cinsiyetlerine daha eşitlikçi yaklaşıktığı saptanmıştır. Bu nedenle alt öğrenim düzeyine sahip olan ebeveynlere çocuklarıyla birlikte mesleklerin toplumsal cinsiyet eşitliği konulu drama atölyeleri uygulanabilir.

- Çocukların yaşları büyüdükçe mesleklerine dair cinsiyet kalıp yargılarının azaldığı ve meslekleri hem kadının hem de erkeğin yapabileceğine dair toplumsal cinsiyet eşitlikçi algının arttığı sonucuna ulaşılmıştır. Bu nedenle küçük yaş gruplarından başlayarak toplumsal cinsiyet eşitliğine dair etkinlikler arttırılabilir ve bu sinıflarla meslek tanıtım etkinliklerinin yapılması ve cinsiyetleştirdikleri mesleklerin zıttı bir cinsiyette meslekten bireyler sınıfa davet ettirilebilir. 


\section{Kaynakça}

Acar Erdol, T. (2019). Practicing gender pedagogy: The case of Egalia. Journal of Qualitative Research in Education, 7(4), 1365-1385. https://doi.org/10.14689/issn.21482624.1.7c.4s.3m

Ahi, B., Cingi, M. A. ve Kıldan, A. O. (2016). 48-60 aylık çocukların öğretmen kavramına yönelik algılarının çizimler aracılı̆̆ıyla incelenmesi. İlköğretim Online, 15(1), 77-90. https://doi.org/10.17051/io.2016.97994

Aktın, K. (2014). Okul öncesi dönemde sosyal bilgiler eğitimi: mesleklerin öğretimine yönelik bir durum çalışması. Turkish Studies, 9(5), 139-155. https://doi.org/10.7827/turkishstudies.6934

Altan Arslan, Ş. (2000). Ders kitaplarında cinsiyetçilik. (1. Basım). Başbakanlık Kadının Statüsü ve Sorunları Genel Müdürlüğü. Ankara.

Altuntaş, O. ve Altınova, H.H. (2015). Toplumsal cinsiyet algısı ile sosyoekonomik değişkenler arasındaki ilişkinin belirlenmesi. Turkish Studies International Periodical For The Languages, Literature and History of Turkish or Turkic, 10(6), 83-100. https://doi.org/10.7827/turkishstudies.7674

Aykaç, N. (2012). İlköğretim öğrencilerinin resimlerinde öğretmen ve öğrenme süreci algısı. Ĕgitim ve Bilim, 164(37), 298-315. https://doi.org/10.7827/turkishstudies.8624

Aylaz R., Güneş G., Uzun Ö. ve Ünal S. (2014). Üniversite öğrencilerinin toplumsal cinsiyet rolüne yönelik görüşleri. Sürekli Tıp Eğitimi Dergisi, 23, 183-189. https://doi.org/10.18301/rss.504

Baker, M., Ali, M. ve French, E. (2018). Effectiveness of gender equality initiatives in project-based organizations in Australia. Australian Journal of Management, 44(3), 425-442. https://doi.org/10.1177/0312896218805809

Bian, L., Leslie, S. J. ve Cimpian, A. (2017). Gender stereotypes about intellectual ability emerge early and influence children's interests. Science, 335 (6323): 389-391. https://doi.org/10.1126/science.aah6524

Cansever Arslan, B. (2017). The children's perceptions of the teacher: An analysis of the drawings created by the children. Inönü University Journal of the Faculty of Education, 18(1), 281291. https://doi.org/10.17679/inuefd.306625

Carole, F. (2011). Boys are doctor, girl are nurses: the resilience of gender as a determinant in the career aspirations of girls. Master Thesis, James Cook University.

Connell, R. W. (1998). Toplumsal cinsiyet ve iktidar: toplum, kişi ve cinsel politika (C. Soydemir, Çev.) İstanbul: Ayrıntı Yayınları.

Çelik, Ö. (2008). Ataerkil sistem bağlamında toplumsal cinsiyet ve cinsiyet rollerinin benimsenmesi. yüksek lisans tezi. Gazi Üniversitesi Sosyal Bilimler Enstitüsü Kamu Yönetimi Anabilim Dal1, Ankara.

Dyck, J.M., Oliffe, J., Phinney, A. ve Garrett, B. (2009). Nursing instructors' and male nursing students' perceptions of undergraduate, classroom nursing education. Nurse Education Today, 29, 649-653. https://doi.org/10.1016/j.nedt.2009.02.003

ETCEP (2017). Eğitimde toplumsal cinsiyet eşitliği. Erişim Tarihi: 18.01.2020. http://etcep.meb.gov.tr/hakkimizda-detayi-1440845992122.

Fang, G. (2010). The psychology of gender (xingbie xinlixue). Anhui Education Press. 
Gökçearslan, A. (2010). Batı kökenli çizgi filmlerde ırkçı, kapitalist ve ayrımcı ideolojik söylem. $E$ Journal of New World Sciences Academy, 5(4), 365-373.

Graham, C. and Chattopadhyay, S. (2013). Gender and well-being around the World. Int. J. Happiness and Development, 1(2), 212-232. https://doi.org/10.1504/ijhd.2013.055648

Günaydın, B. (2011).Çocuklara yönelik programlarda toplumsal cinsiyet rollerinin sunumu: TRT çocuk ve yumurcak tv. Uzmanlık Tezi, T.C. Radyo ve Televizyon Üst Kurulu, Ankara.

Gündüz Çetin, H. ve Tarhan, S. (2017). İlköğretim öğrencilerinin meslek seçimlerine yönelik tutumlarında toplumsal cinsiyetin etkisi. Ilköğretim Online, 16(3), 1287- 1300. https://doi.org/10.17051/ilkonline.2017.330258

Halim, M. L., Ruble, D., Tamis-LeMonda, C. ve Shrout, P. E. (2013). Rigidity in gender-typed behaviors in early childhood: A longitudinal study of ethnic minority children. Child Development, 84(4), 1269-1284. https://doi.org/10.1111/cdev.12057

Haskan Avc1, Ö., Karababa, A. ve Zencir, T. (2018). Male pre-school teacher candidates in the context of gender: Perceived challenges and future concerns. Hacettepe University Journal of Education. Advance online publication. doi: 10.16986/HUJE.2018046235.

Heredia, E. B. (2007). Equilibrio de genero en la preparacion profesional. Revista Fuentes, 7, 6-19.

Kalaycı, N. ve Hayırsever, F. (2014). Toplumsal cinsiyet eşitliği bağlamında vatandaşlık ve demokrasi eğitimi ders kitabına yönelik bir inceleme ve bu konuya ilişkin öğrenci algılarını belirleme. Kuram ve Uygulamada Ĕ̆itim Bilimleri Dergisi - KUYEB (Educational Sciences: Theory \& Practice), 14 (3), 1 -26. https://doi.org/10.12738/estp.2014.3.1813

Karabekmez, S., Yıldırım, G., Özyılmaz Akamca, G., Ellez, A. M. ve Bulut Üner, A. N. (2018). Okul öncesi dönem çocuklarının mesleklere yönelik toplumsal cinsiyet algılarının incelenmesi. Science, Education, Art and Technology Journal, 2(1), 52-70.

Karasar, N. (2015). Araştırmalarda rapor hazırlama (19. Basım). İstanbul: Nobel Yayınları.

Kaynak, D., ve Aktaş, E. (2017). Okul öncesi hikaye ve masal kitaplarında toplumsal cinsiyet rolleri. Ekev Akademi Dergisi, 21(72), 67-85.

Kodan Çetinkaya, S. (2013). Üniversite öğrencilerinin şiddet eğilimlerinin ve toplumsal cinsiyet rollerine ilişkin tutumlarının incelenmesi. Nesne, 1 (2), 21-43.

Kuzlak, A, Çuvaş, B. ve Sakallı-Uğurlu, N. (2017). Anne ve babaların eğitim düzeyi ve mesleki statüleri ile üniversite öğrencilerinin cinsiyetçilik ve muhafazakârlığı arasındaki ilişki. Nesne, 5(9), 89-109.

Nicolao, J. S. (2014). The effects of gender stereotyping on career choice among secondary students in Dar es Salaam (Doctoral dissertation). The Open University Of Tanzania.

Ocak Karabay, Ş., Güzeldere Aydın, D., Kanbur, B. N. ve Tunç, M. (2018). Evaluation of awareness levels of five year old children on social gender equality. Uluslararası Sosyal Araştırmalar Dergisi, 11(61), 686-696. https://doi.org/10.17719/jisr.2018.2961

Pehlivan, S. ve Gökbulut, Ö. Ö. (2015). Yaratıcı drama yöntemi ile okul öncesi dönem çocuklarına mesleklerin tanit1lmasi. Yaratıcl Drama Dergisi, 10(1), 39-50. https://doi.org/10.21612/yader.2015.004

Perea, K (2011) Girl cartoons: A playful transgression on popular culture's compulsory gender coding. Doctoral dissertation. Retrieved from UMI Dissertation Publishing, ProQuest (Accession No. 3458313). 
Pınar, G., Taşkın, L. ve Eroğlu, K. (2008). Başkent Üniversitesi öğrenci yurdunda kalan gençlerin toplumsal cinsiyet rol kalıplarına ilişkin tutumları. Hacettepe Üniversitesi Sağllk Bilimleri Fakültesi Hemşirelik Dergisi, 15(1), 47-57.

Ramaci, T., Pellerone, M., Ledda, C., Presti, G., Squatrito, V. ve Rapisarda, V. (2017). Gender stereotypes in occupational choice: A cross-sectional study on a group of Italian adolescents. Psychology Research and Behavior Management, 10, 109-117. https://doi.org/10.2147/prbm.s134132

Ruble, D. N., Taylor, L. J., Cyphers, L., Greulich, F. K., Lurye, L. E., ve Shrout, P. E. (2007). The role of gender constancy in early gender development. Child Development, 78(4), 11211136. https://doi.org/10.1111/j.1467-8624.2007.01056.x

Shapiro, J. R. ve Williams, A. M. (2012). The role of stereotype threats in undermining girls' and women's performance and interest in STEM fields. Sex Roles: A Journal of Research, 66(34), 175-183. https://doi.org/10.1007/s11199-011-0051-0

Samara, G., Bonoti, F. ve Christidou, V. (2012). Exploring children's perceptions of scientists through drawings and interviews. Social and Behavioral Sciences, 46, 1541-1546. https://doi.org/10.1016/j.sbspro.2012.05.337

Somer, B. ve Değirmenci, G. Y. (2015). Resimli çocuk kitaplarının toplumsal cinsiyet kavramı açısından incelenmesi. Ejer Conference 2015, 8-10 Haziran 2015, Ankara.

Taşdemir Akkavak, D. ve Sarıkaya Karabudak, S. (2019). Hastanede yatan okul çağı çocukların hemşireyi ve hastaneyi algılama durumlarının incelenmesi. Dokuz Eylül Üniversitesi Hemşirelik Fakültesi Elektronik Dergisi, 12(1), 46-56.

Terzioğlu, F. ve Taşkın, L. (2008). Kadının toplumsal cinsiyet rolünün liderlik davranışlarına ve hemşirelik mesleğine yansımaları. Cumhuriyet Üniversitesi Hemşirelik Yüksekokulu Dergisi, 12(2), 62-67.

Thompson, T. L., ve Zerbinos, E. (1995). Gender roles in animated cartoons: Has the pictured changed in 20 years?. Sex Roles, 32, 651-674. https://doi.org/10.1007/bf01544217

Van der Vleuten, M., Jaspers, E., Maas I. ve Van der Lippe T. (2016). Boys' and girls' educational choices in secondary education. The role of gender ideology. Educational Studies, 42(2), 181-200. https://doi.org/10.1080/03055698.2016.1160821

Varol, Z. , Çiçeklioğlu, M. ve Taner, Ş . (2016). Bir tıp fakültesi birinci sınıf öğrencilerinde toplumsal cinsiyet alg1 düzeyi ve ilişkili faktörlerin değerlendirilmesi. Ege Tip Dergisi , 55(3), 122-128 . DOI: 10.19161/etd.344208. https://doi.org/10.19161/etd.344208

Vatandaş, C. (2007), Toplumsal cinsiyet ve cinsiyet rollerinin algılanışı, Sosyoloji Konferansları Dergisi, 2(35), 29-56.

World Economic Forum (WEF), (2018). The global gender gap report, http://reports.weforum.org/global-gender-gap-report-2018/ (Erişim: 24.06.2019).

Wiersma, Beth A. (2000). The gendered world of disney: a content analysis of gender themes in full-length animated disney feature films. Brookings: South Dakota State University.

World Bank (2019). The little data book on gender 2019. World Bank, Washington, DC. (C World Bank. https://openknowledge.worldbank.org/handle/10986/31689 License: CC BY 3.0 IGO.

Yağan Güder, S. (2014). Okul öncesi dönemdeki çocukların toplumsal cinsiyet algılarının incelenmesi. Yayınlanmamış doktora tezi. Hacettepe Üniversitesi Eğitim Bilimleri Enstitüsü, Ankara. 